\title{
'Not in our name without us' - The intervention of Catholic Women Speak at the Synod of Bishops on the Family: A case study of a global resistance movement by Catholic women
}

Author:
Nontando Hadebe ${ }^{1}$
Affiliation:
'Department of Philosophy,
Systematic and Practical
Theology, University of South
Africa, South Africa
Corresponding author:
Nontando Hadebe,
noehadebe@gmail.com
Dates:
Received: 11 May 2016
Accepted: 13 Aug. 2016
Published: 22 Nov. 2016
How to cite this article:
Hadebe, N., 2016, “'Not in
our name without us" - The
intervention of Catholic
Women Speak at the Synod
of Bishops on the Family: A
case study of a global
resistance movement by
Catholic women', HTS
Teologiese Studies/
Theological Studies $72(1)$,
a3481. http://dx.doi.
org/10.4102/hts.v72i1.3481
Read online.
Copyright:
@ 2016. The Authors.
Licensee: AOSIS. This work
is licensed under the
Creative Commons
Attribution License.

This article will illustrate through a case study of the intervention of the Catholic Women Speak Network (CWSN) at the Synod of Bishops on the Family, the dynamic movement within Steyn's Critical Diversity Literacy theory from 'reading' the social script of injustice to conscientisation and finally actions for transformation, a methodology similar to that of feminist theologies. In the Catholic Church power, privilege and leadership are institutionalised in the hands of celibate males, and in the context of the Synod they had power to vote on teachings on family life. This hegemony that excludes women's voices and essentialises women was challenged by the CWSN, illustrating connections between theory and praxis as well as diversity as a critical tool of resistance.

\section{Introduction}

Despite the theme of the Synod, those gathered did not engage with the work of women theologians who have for many years been writing on issues of marriage, family life, sexuality and human relationships. In other words, women's voices were not heard in a way that would authentically represent the vast diversity of Catholic women's lives, nor was the contribution of women theologians acknowledged. In this article, we speak as some of those missing voices (Catholic Women Speak Network 2015:xxix).

One of the defining characteristics of the Catholic Church is an exclusive male celibate leadership invested with power to determine orthodoxy and orthopraxis. Hence the Synod of Bishops on the Family ${ }^{1}$ had the power to exclude the work of women theologians and the 'vast diversity of Catholic women's lives' by not making any reference to these sources in their deliberations and decisions. Significantly however the emphasis by the Catholic Women Speak Network (CWSN) on diversity in women's lives constitutes an act of resistance as it subverts dominant theologies within Catholicism that essentialise and homogenise women while at the same time teaching the equality of women and men based on their creation in the image of God (imago Dei). Feminist theologians challenge this unequal equality status of women. Diversity therefore is not mere inclusion, it is a subversive tool of resistance against beliefs and practices that sustain and legitimate exclusion and inequality. This view of diversity is also central to Melissa Steyn's (2015) Critical Diversity Literacy (CDL) theory developed from experiences of economic inequality and social exclusion by university students from a previously disadvantaged background in post-apartheid South Africa. Steyn challenges discourses that promote diversity without interrogating structures and power relations that sustain and perpetuate inequality and proposes a theoretical framework consisting of 10 principles that empower students with analytical critical skills to decipher inequality so that they can ultimately take action for justice and transformation. This framework resonates with feminist methodologies used by the CWSN that start with women's experiences of oppression and end with the call to justice, inclusion and equal participation of women. This article will critically examine the intervention of the CWSN in dialogue with some key principles from Steyn's CDL theory. The rest of the article will discuss these issues further according to the following outline: unequal equality of women in the Catholic Church; background to the Synod of Bishops on the Family; a summary of Steyn's CDL

1.The Synod referred to is the 'Synod of Bishops on the Family' convened by Pope Francis and held in Rome from 4 to 25 October 2015 Only the bishops had the power to vote and none of the other participants comprising of 14 married couples, 25 women and representatives from other Christian denominations. Accessed 3 February 2016, from http://americamagazine.org/content/all-things/ where-were-voting-women-synod-0 
theory; critical dialogue between CWSN and some key concepts from Steyn's CDL theory; and conclusion.

\section{The unequal equality of women in the Catholic Church}

The discussions on unequal equality of women in the Catholic Church will be limited to teachings on equality between women and men that essentialise and homogenise women and promote complementary relationships between the sexes which justify the exclusion of women from ordained priesthood. This exclusion as mentioned earlier denies women access to power that determines orthodoxy and orthopraxis. A sample of three influential texts frequently referred to in debates on the status of women in the Catholic Church, ${ }^{2}$ will be briefly discussed namely, the Catechism of the Catholic Church (2003) and the two letters to women written by Pope John Paul II entitled Apostolic Letter of the Supreme Pontiff John Paul II Mulieris Dignitatem on the Dignity and Vocation of Women on the occasion of the Marian year (1988) hereinafter referred to in its abbreviated form as the Mulieris Dignitatem and The Letter of Pope John Paul II to Women ${ }^{3}$ written in response to the Fourth Conference of Women held in Beijing, China (1995:n.p.).

The Catechism of the Catholic Church (2003) teaches the equality and dignity of women and men, their fundamental differences and advocates against any form of discrimination as reflected in the following sections:

369. Man and woman have been created, which is to say, willed by God: on the one hand, in perfect equality as human persons; on the other, in their respective beings as man and woman. 'Beingman' or 'being-woman' is a reality which is good and willed by God: man and woman possess an inalienable dignity which comes to them immediately from God their Creator. ${ }^{240}$ Man and woman are both with one and the same dignity 'in the image of God'. In their 'being-man' and 'being-woman', they reflect the Creator's wisdom and goodness.

1935. The equality of men rests essentially on their dignity as persons and the rights that flow from it:

Every form of social or cultural discrimination in fundamental personal rights on the grounds of sex, race, color, social conditions, language, or religion must be curbed and eradicated as incompatible with God's design. (Catechism of the Catholic Church 2003:n.p.)

Similarly, Pope John Paul II in the Mulieris Dignitatem confirms the teachings on equality and basis as their creation in the image of God (imago Dei): 'both man and woman are human beings to an equal degree, both are created in God's image' (6, 1988:n.p.). Further, the imago Dei is sexually differentiated between 'being-woman' and 'being-man' as stated in the Catechism. These differences between women and men are

2.Examples of organisations that use these texts are numerous and include Bishops conferences such as Southern African Bishops Conference (www sacbc org za), United conferes catic Bishops Conference (www.usccb.org) Caritas (ww caritas org) States Catholich as Women's Ordination (www.womenpriests.org), www.romancatholicwomepriests.

3.These documents are downloaded from the Vatican website and do not have page numbers, each paragraph has a number and that is the number that is used in references in text. according to The Letter of Pope John Paul II to Women not incidental but ontological that is being a woman is fundamentally different from being a man: 'Womanhood and manhood are complementary not only from the physical and psychological points of view, but also from the ontological. It is only through the duality of the "masculine" and the "feminine" that the "human" finds full realization' (Pope John Paul 7, 1995:n.p.). These ontological differences are not neutral but are definitive of the nature of women and men and prescribe the differential power relationships ascribed to them. Pope John Paul II elaborates on these differences through the application of what he refers to as the 'Marian principle' and the 'Apostolic-Petrine principle' (11, 1995:n.p.). The Marian principle means that Mary is the prototype for women as she is the dignity and vocation of women, of each and every woman $(11,1988: n . p$.$) who embodies motherhood and$ virginity which are the two particular dimensions of the vocation of women in the light of divine Revelation" (7, 1988:n.p.). She is both virgin and mother: These two dimensions of the female vocation were united in her in an exceptional manner, in such a way that one did not exclude the other but wonderfully complemented it (17, 1988:n.p.). Virginity for women is either prior to marriage or a choice to be celibate spouse of Christ defined as 'spiritual motherhood' in service of the church and world:

In the life of consecrated women, for example, who live according to the charism and the rules of the various apostolic Institutes, it can express itself as concern for people, especially the most needy: the sick, the handicapped, the abandoned, orphans, the elderly, children, young people, the imprisoned and, in general, people on the edges of society. (21, 1988:n.p.)

The role of women in the workplace and society is also affirmed by Pope John Paul II through his concept of the 'genius of women' which differentiates them from men and is the basis of their unique contribution to the world:

in this phrase a specific part of God's plan which needs to be accepted and appreciated, but also in order to let this genius be more fully expressed in the life of society as a whole, as well as the life of the Church. (10, 1995:n.p.)

However, as will be evident from the 'Petrine Principle' the unique qualities of women that differentiate them from men are the basis of their exclusion from access to positions of power that as indicated earlier determine orthodoxy and orthopraxis.

Through the 'Petrine principle' Pope John Paul II, applies a Christological argument for the exclusion of women from priesthood. Two choices are at the centre of the argument namely the choice of the male as the representation of God in the person of Jesus as well as the choice of an all-male group of 12 disciples by Jesus. He argues for the preferential option of the male as follows:

If Christ-by his free and sovereign choice, clearly attested to by the Gospel and by the Church's constant Tradition-entrusted only to men the task of being an 'icon' of his countenance as 'shepherd' and 'bridegroom' of the Church through the exercise of the ministerial priesthood, this in no way detracts from the role of 
women, or for that matter from the role of the other members of the Church who are not ordained to the sacred ministry, since all share equally in the dignity proper to the 'common priesthood' based on Baptism. (11, 1995:n.p.)

Accordingly, the Petrine principle gives divine sanction to the unequal equality of women in two ways. Firstly, women's inequality is in their exclusion from ministerial priesthood because they are non-males and as mentioned earlier are by extension denied access to power that determines orthodoxy and orthopraxis. Furthermore, the sacramental nature of priesthood as representing Christ that is in persona Christi can only be expressed by males who are the 'icons' of Jesus because he was male. Because the differences between women and men are said to be ontological, there is no possibility according to this argument of women being able to represent Jesus and by implication become priests. Secondly, by including women in the 'common priesthood' Pope John Paul II seems to propose an alternative priesthood that is accessible to all. However, the common priesthood does not have the same status and power as the ministerial priesthood. Therefore, in this respect the common priesthood of women perpetuates their exclusion and marginalisation.

In response to their exclusion, women have not been silent. Feminist theologians continue to challenge and resist these theologies of exclusion. Two examples will be discussed namely the application of gender theories to challenge essentialist views of women that lie at the heart of exclusion and unequal equal status and the reduction of the identity of Jesus to his maleness.

Firstly, gender theories challenge biological determinism, and essentialist theories that homogenise and prescribe fixed identities for women and men based on their sex which justifies and naturalises unequal power relations between the sexes. Gender theory makes a distinction between sex and gender. Dowsett explains this difference as follows: we are born biologically sexed, but society en-genders us [...] we are socialized into two forms of character and behaviour: feminine and masculine" (2003:23). In other words one is born male or female and is socialised into becoming a woman or a man. Minas (2000:5) and Kiguwa (2004:7-1) describe gender as the social construction of sex. The power of defining gender as a social construction is that femininities and masculinities can be deconstructed and reconstructed. This distinction between sex and gender became a powerful political tool for feminists advocating for change in the status of women. Clifford defines feminism as a social vision, rooted in women's experience of sexually based discrimination and oppression, a movement seeking the liberation of women from all forms of sexism and an academic method of analysis being used in virtually every discipline (2001:16). In the discipline of theology, feminist theologians according to Ruether question patterns of theology that justify male dominance and female subordination such as exclusive male language for God, the view that males are more like God than females (2002:3).
Not surprisingly, gender theories have come under intense criticism from the Catholic Church because they undermine the central arguments of both the Marian and Petrine principles that sustain ontological differences between women and men. For example Pope Francis quoted by the National Catholic Reporter refers to gender ideology which according to him seeks to blur the differences between women and men, as the designs of death, that disfigure the face of man and woman, destroying creation' (McElwee 2015:n.p.). The Pope also places gender ideology alongside nuclear arms as a destructive force: 'Let's think of the nuclear arms, of the possibility to annihilate in a few instants a very high number of human beings' and 'Let's think also of genetic manipulation, of the manipulation of life, or of the gender theory, that does not recognize the order of creation' (2015:n.p.).

Secondly feminist theologians such as Elizabeth Johnson have argued against the reduction of the identity of Jesus to his maleness:

The fact that Jesus of Nazareth was a man is not in question. His maleness is constitutive for his personal identity, part of the perfection and limitation of his historical reality and is such it is to be respected. His sex is as intrinsic to is historical person as are his race, class, ethnic heritage, culture, his Jewish religious faith, his Galilean village roots, and so forth. The difficulty arises, rather from the way this one particularity of sex unlike the other historical particularities, is interpreted in sexist theology and practice. Consciously or unconsciously, Jesus' maleness is lifted up and made essential for his Chistoric function and identity, thus blocking women precisely because of their female sex from participating in the fullness of their Christian identity as images of Christ. (1993:118-119)

Johnson's argument goes to the heart of the Petrine principle by confronting the inconsistencies that emanate from the focus on only one aspect of the historical particularity of Jesus. The exclusion of the diverse and multiple characteristics of Jesus further illustrates the role of diversity as a tool of resistance by women against a reductionist Christology that is used to legitimate their exclusion and marginalisation.

The next section on the background to the Synod of Bishops on the Family and some of the contested teachings on the family in the Catholic Church provides the context for the intervention by CWSN.

\section{The Synod of Bishops on the Family}

This section will briefly discuss the background to the Synod, the findings of the consultative process that included members of the Church across the world and some contested teachings on the family.

As preparation for the Synod, Pope Francis convened the Extraordinary General Assembly of the Synod of Bishops on 8th October 2013 to deliberate on the topic: The Pastoral Challenges of the Family in the Context of Evangelization (Instrumentum Laboris 2014), hereinafter referred to in its abbreviated form as Instrumentum Laboris. A preparatory document was 
presented to the Synod and later questionnaires were sent to bishops all over the world to be distributed to the laity to ensure their participation in the process. The inclusion of the laity may seem like a unique innovation by Pope Francis but that is not the case as it is in continuity with the tradition and practice within the history of the Catholic Church of recognizing in the faith of the laity the authority to discern the truth of the gospel in a given context as explained in the following quotation from the International Theological Commission:

The faithful have an instinct for the truth of the Gospel, which enables them to recognize and endorse authentic Christian doctrine and practice, and to reject what is false. That supernatural instinct, intrinsically linked to the gift of faith received in the communion of the Church, is called the sensus fidei, and it enables Christians to fulfil their prophetic calling. (2, 2014:n.p.)

The findings from the responses of the laity were compiled and reflected in the Instrumentum Laboris (2014). A recurring theme in the document is the disjuncture between the official teachings of the Catholic Church and the practices and attitudes of members: 'A vast majority of responses highlight the growing conflict between the values on marriage and family as proposed by the Church and the globally diversified social and cultural situations' (IL 15, 2014:n.p.). This gap was also confirmed through research on the synodal process by independent companies. Claque cites research carried out in 12 countries across the world which together comprise $60 \%$ of Catholics where the findings revealed the same gap:

Taken together, these findings suggest an extraordinary disconnect between the church's basic teachings on the fundamental issues of family and pastoral responsibilities and the viewpoints currently held by many of the world's more than 1 billion Catholics. (2015:53)

Some of the contested teachings on the family include, the use of contraceptives, divorce and remarriage and same-sex unions all of which are condemned by the Church. For example in Humanae Vitae (1968) the use of contraceptives is rejected as a means of family planning. Its use is absolutely excluded as lawful means of regulating the number of children (14, 1968:n.p.). The document proposes natural family planning: 'the Church teaches that married people then take advantage of the natural cycles immanent in the reproductive system and engage in marital intercourse only during those times that are infertile' (16, 1968:n.p.). Divorced and remarried persons are excluded from the Eucharist based on the indissoluble of marriage: if these people were admitted to the Eucharist, the faithful would be led into error and confusion regarding the Church's teaching about the indissolubility of marriage' (Congregation for the Doctrine of the Faith 7, 1994:n.p.). Same-sex unions are also condemned on the basis that recognised marriage is exclusively between a woman and man as described in the following quotation:

There are absolutely no grounds for considering homosexual unions to be in any way similar or even remotely analogous to God's plan for marriage and family. Marriage is holy, while homosexual acts go against the natural moral law. Homosexual acts 'close the sexual act to the gift of life. They do not proceed from a genuine affective and sexual complementarity. Under no circumstances can they be approved'. (Congregation for the Doctrine of the Faith, 4 2003:n.p.)

As already mentioned there is a disjuncture between the beliefs and values of many Catholics and the teachings of the Church. Furthermore, the laity pointed out that the moral authority of the Church had been weakened by child abuse scandals:

Responses from almost every part of the world frequently refer to the sexual scandals within the Church (pedophilia, in particular) and, in general, to a negative experience with the clergy and other persons. Sex scandals significantly weaken the Church's moral credibility, above all in North America and Northern Europe. (IL 75, 2014:n.p.)

These findings from diverse continents and members of the Catholic Church illustrate the contested nature of the power of the hierarchy shown in the disparity between the teachings of the Church and the practices of Catholics. The sensus fidelium is challenging the official teachings of the Catholic Church on the family. Interestingly Pope Francis in his PostSynodal Apostolic Exhortation Amoris Laettia (The Joy of Love) released on 8th April 2016 adopted a pastoral approach that was more nuanced and less prescriptive while still upholding the Church's teachings on the family. A full discussion on the exhortation is beyond the scope of this paper, but three examples will be briefly mentioned to illustrate some surprising elements of the document. The first example is that of a less 'top-down' approach on determining practices related to the family: 'I would like to make it clear that not all discussions of doctrinal, moral or pastoral issues need to be settled by interventions of the magisterium' (Pope Francis 2016:3). The second comment is on the status of women and a veiled affirmation of feminism: 'If certain forms of feminism have arisen which we must consider inadequate, we must nonetheless see in the women's movement the working of the Spirit for a clearer recognition of the dignity and rights of women' (2016:44). Finally an example of compassion without change in the teachings of the Church as is the case on homosexuality:

We would like before all else to reaffirm that every person, regardless of sexual orientation, ought to be respected in his or her dignity and treated with consideration while every sign of unjust discrimination is to be carefully avoided, particularly any form of aggression and violence. (2016:190)

Pope Francis however, reiterated the teachings of the Church against same-sex marriage when he stated that there are absolutely no grounds for considering homosexual unions to be in any way similar or even remotely analogous to God's plan for marriage and family' (2016:190). The pastoral approach by Pope Francis seems like a compromise between the changing views of the laity and the teachings of the Church.

Before discussion the intervention and resistance of the CWSN a brief overview of Steyn's CDL theory will be 
discussed as it forms the comparative framework for further discussions on diversity as a resistance tool.

\section{Critical diversity literacy theory by Melissa Steyn}

As mentioned in the introduction the main reasons for choosing to engage Steyn's (CDL) theory with the resistance work of the CWSN is that diversity is central to the struggle against inequality and exclusion in both contexts and a similar methodology is used that starts with a critical analysis of the social context of injustice through the experiences of oppressed groups and concludes with a call to action against injustice.

In post-apartheid South Africa, diversity is often constructed according toSteynin'apolitical, individualized conceptualization of differences to serve the interest of those who are already centred economically, socially and organizationally' (2015:380). For students from marginalised backgrounds who form the interlocutors of Steyn's theory, economic and social inequalities militate against diversity as an experience of equality. Hence, an uncritical appropriation of diversity fails to address the persistent inequalities that characterise post-apartheid South Africa where 'privilege and oppression operate along other axes of difference' (2015:379). In response to unequal equality, CDL operates as both theory and practice. It is a 'social theory pertaining to questions of diversity, difference and otherness' ( $p$. 379) and a practice that is:

an informed analytical orientation that enables a person to 'read' prevailing social relations as one would a text, recognizing the ways in which possibilities are being opened up or closed down for those differently positioned within the unfolding dynamics of a specific social context. (Steyn 2015:381)

As a theory $C D L$ provides a conceptual framework for analysing intersecting oppressions emanating from difference and otherness. For example a lesbian black student with disabilities from a poor home is subject to multiple intersecting oppressions based on categories of difference such as gender, race, class, disability and sexual orientation. On the other hand a white, middle-class student has access to multiple privileges based on their racial and class differences. In both these cases the historical legacies of apartheid and colonialism are critical to understanding and confronting contemporary expressions of oppression and privilege. It is in this context of inequality that $C D L$ as a practice aims to empower students to 'read' their social contexts of either oppression or privilege in order to decipher the mechanisms of power that create and sustain inequality. Steyn proposes 10 principles to apply in the struggle against intersecting systems of oppression. These principles will be described briefly.

The first principle is the critical reading of the context in order to identify systems of power underlying the construction of differences as inequality and how these systems are created and sustained (Steyn 2015:381). One way that these differences are legitimated is through the creation of groups that are in oppositional relationships with each other for example women versus men; black versus white and heterosexual versus homosexual. These differences according to Steyn are responsible for "oppressive social structures [that] maintain the categories, conferring or withholding rewards such as exclusion, belonging and acceptance or conversely administering exclusion and censure" (2015:381). Consequently, deciphering the ways in which powerful groups sustain and perpetuate inequality within a democracy is a critical tool of resistance to counter a superficial form of diversity that does not confront inequality and inequity.

The second principle is the recognition of 'unequal symbolic and material value of different social locations' of privilege and power such as 'whiteness, heterosexuality, masculinity, cisgender, ablebodiedness, middleclassness' (2015:382). This principle focuses on the multiple ways, beliefs and practices privilege certain groups based on the categories of 'oppositional differences' discussed in the previous principle. These systems and ideologies that sustain privilege must be interrogated and deconstructed in the struggle for equality among groups.

The third principle identified the analytical skills required to decipher the intersectionality of systems of oppression that is; 'how these systems of oppression intersect, interlock, coconstruct and constitute each other and how they are reproduced, resisted and reframed' (2015:383). This principle highlights the intersectionality of oppression mentioned earlier, where some groups are subject to multiple oppressions based on a combination of any of these social indicators such as race, class, sexual orientation, disability and gender. The significance of this principle is that it militates against the reduction of oppression into one category that fails to account for differences among oppressed groups. For example an exclusive focus on racial oppression often ignores other forms of oppression operating within an oppressed group such as class, sexual orientation and gender. Thus the intersectionality of multiple sites of oppressions re-enforces the critical role of diversity within oppressed groups as critical to the liberation of all groups.

The fourth principle links the present with the past as inseparable realities because the current economic inequality and racism in South Africa cannot be understood without reference to the historical legacies of apartheid and colonialism: 'When we depoliticize the present by refusing a critical me', (Steyn 2015:383). Without addressing the historical legacies, the struggle to overcome the economic and social systems that perpetuate inequality and racism in post-apartheid South Africa would be compromised and ineffective.

The fifth principle focuses on identities as socially constructed and perpetuated through daily social interactions and practices: 'social identities are learned and are an outcome of social practices,' (Steyn 2015:385). Social identities are reflected in group identities which assign particular 
characteristics to all persons belonging to the group through stereotypes used to sustain inequality and privilege. These stereotypes ignore the historical contexts that shaped group experiences and identities. For example racism, apartheid, colonialism shaped all race groups in South Africa and generated stereotypes that perpetuated difference and inequality. These historical constructions of group status and difference continue to operate in post-apartheid South Africa and need to be confronted as an integral part of the struggle against all forms of oppression and privilege.

The sixth principle is the possession of a diversity grammar and a vocabulary that facilitates a discussion on privilege and oppression, (Steyn 2015:385). This skill empowers oppressed groups to enter into the world of privileged groups and identify ways in which their identities and issues are framed from a position of power and privilege and to then subvert these categories through developing their own vocabulary of resistance. For example challenging historical narratives that exclude the contribution and voices of oppressed groups. By developing their own language of resistance oppressed groups develop the capacity to 'recognize, point out and insist on the reality of the practices, strategies and effects of the operations of power on difference,' (Steyn 2015:385). In this principle the agency of the oppressed is recognised as critical for all discourses on resistance and struggles against multiple forms of oppression.

The seventh principle is the ability to 'translate (see through) and interpret coded hegemonic practices' because 'hegemonic language tends to obfuscate the ways in which social control is being exercised' (Steyn 2015:386). In this principle Steyn recognises that oppressed groups need to be vigilant in dealing with powerful groups who often mask their exercise of power and control in subtle ways that are not easy to discern. In order to penetrate the 'coded hegemonic practices' oppressed groups need to be able to learn and interpret the language and strategies used by powerful groups to sustain the status quo and stifle dissent.

The eighth principle is an 'analysis of the ways that diversity hierarchies and institutionalised oppression are inflected through specific social contexts and material arrangements' (Steyn 2015:386), that is the 'politics of location, the particularities of place, time and specific ways in which people live within and through their material worlds' (2015:386). This principle requires a contextual approach to oppression that is true to the context and its material reality. For example violence against women is a global phenomenon but is expressed differently in each context and needs to be confronted in its local manifestation. Thus the intersection of the material world of politics, economics and history is context specific, and therefore the struggle against oppression must respond to the challenges in each context.

The ninth principle emphasises the often ignored role of emotions as precursors of actions that either support or subvert social injustice. According to Styen, emotions:

affect us in patterned ways such as who we should move towards, who away from; who to connect; who to separate from; who to protect, who to repulse. All such flows of affect are operative within systems of power and have special effects. (2015:387)

Emotions therefore, are powerful social determinants of behaviour and attitudes in inter-group relationships and have far-reaching consequences that shape practices of exclusion and inclusion, respect and disrespect, love and hate. These practices are enacted in daily social interaction and sustain prejudice.

The last principle is praxis that is critically informed active participation in the struggle against oppression and privilege which Steyn describes as 'engagement with issues of the transformation of these oppressive systems towards deepening social justice at all levels of social organization', which translate to 'the willingness to bring together theory and practice in everyday life' (Steyn 2015:387). Thus the culmination of the foregoing nine principles is to empower oppressed and privileged groups with tools that will enable them to be actively engaged in the struggle for justice and transformation as a pre-requisite for building a diverse society in South Africa.

These principles form the framework for discussing the case study of the intervention by the CWSN at the Synod of Bishops on the Family.

\section{A dialogue between Steyn and Catholic Women Speak Network (CWSN): A case study}

This section will begin with a brief introduction of the CWSN and their intervention at the Synod of Bishops on the Family in October 2015 as context for a critical dialogue with some aspects of Steyn's CDL theory.

The CWSN was initially established as a Facebook group by Professor Tina Beattie. The purpose of the group was to discuss the status of women in the context of the papacy of Pope Francis. For Beattie and members of the CWSN, there was no marked improvement in the status of women as reflected in the following observation:

Like many others, I was beginning to realize that tackling the issue of the role of women in the church was not one of Pope Francis's priorities, however much he acknowledged the problem. The initial euphoria of his election was gradually being replaced by the realization that we women would continue to be joked about, patronized, and romanticized, but the chances of our being treated as full and equal members of Christ's church seemed as remote as ever. (Beattie 2016:1)

The group as noted in the introduction is diverse in nationality, race, profession, marital status and sexual orientation. They produced a book entitled Catholic Women Speak. Bringing Our Gifts to the Table which encapsulates their diversity as critique of the Church's teaching on women and the family and is also a protest against the exclusion of women's voices and experiences from the Synod of Bishops 
on the Family. Beattie (2016) describes the diversity of contributions as follows:

Contributions included reflections on Scripture, history, and theology; on marriage and family life, divorce and remarriage, and same sex love; on motherhood, sexuality, and birth control; on celibacy and the single life; on poverty, migration, and violence; and on women in church institutions and structures. (p. 2)

The strength of the book lies in its ability to speak in the plural reflecting the diversity of women's theologies and experiences of the teachings of the Church on the family. Orobator (2015) in his foreword of the book describes the strength of the diversity of the book as follows:

The narratives voiced by contributors to this anthology are at times joyful and jolting, consoling and painful, exhilarating and exasperating. They tell of 'the joys and hopes, the griefs and anxieties' that Catholic women live and experience in multiple forms of human sexuality, family, marriage, and relationships. They lament the painful exclusion, violence, and poverty that compound these experiences, and question the institutions and structures that sustain them, but without abandoning faith and hope-that each story will be heard, received, and affirmed with compassion, mercy and humility. (p. xii-)

CWSN uses women's diverse experiences of multiple oppressions in relation to the teachings of the Church on the family as well as theologies that deny women the power to participate equally in decisions affecting orthodoxy and orthopraxis. Similarly Steyn's CDL theory also starts with the experiences of exclusion and inequality as a framework for analysing oppressive power structures. Furthermore, as noted in the above quotation, the affective dimension mentioned in Steyn's CDL as a site of resistance is also a key feature in the narratives of the authors of the book. Several authors who write from their personal experiences and express their emotions as part of their critique of the teachings of the Church: Cannon writes about her experience of divorce in the light of the Church's teaching on the indissolubility of marriage:

That 'Church-approved' marriage lasted four profoundly damaging years, in which I was exposed to mental cruelty and abuse as well as serial infidelity and ended 6 months after our daughter was born. (Cannon 2015:83)

Espinoza and Horner comment on the detrimental effect of natural family planning on couples as 'especially stressful for couples who know that pregnancy would pose a grave health risk' (Espinoza \& Horner 2015:94); and Halligan on same same-sex love 'I loved a girl and I knew that wasn't right; my mind was constantly plagued with fear that I was a lesbian. I hated myself. I felt useless and worthless and very small and stupid '(Halligan 2015:114).

In terms of methodology, the authors appropriate the methodology of feminist theologians that start with women's experiences of oppression as the lens through which to interpret theology and tradition. This is similar to Steyn's first step of reading the social script of injustice through the lens of oppressed students. For example, feminist theologian
Elizabeth Schüssler Fiorenza (1998) describes and locates her theology not in academia but in the 'ekklesia of wo/men' because:

Wo/men have the authority to assess and evaluate scholarly interpretations and biblical texts themselves. Such a stress on wo/men's authority and agency stands in tension with both traditional teachings on scriptural authority and the dominant positivistic paradigms of academic scholarship. (p. 86)

By locating their theology in women's experiences of oppression, feminist theologies as noted in the earlier definition of feminist theology by Clifford also critique theology and tradition framed in patriarchal, androcentric and sexist terms that justify the exclusion and subordination of women. Ruether summarises this point when she describes the work of feminist theologians as:

reconstructing the basic theological symbols of God, humanity, male and female, creation, sin and redemption and the church, in order to define these symbols in a gender-inclusive and egalitarian way. (2002:3)

In continuity with feminist theologies and methodologies the introduction of the book CWSN rejects the essentialising discourses on women as discussed earlier and reflected in the following quotation:

We resist, therefore, any suggestion that the Church needs a theology of 'Woman' or 'womanhood'. Rather than a deeper theology of women, we say that the Church needs a deeper theology of the human - a theological anthropology that can be developed only by the full inclusion of women in the process of theological reflection informed by the experiential realities of daily life. (Editorial Team 2015:xxix-)

Concurring with this critique, some of the chapters challenge specific teachings of the Church from theological, contextual and experiential perspectives. Del Rio Mena from Latin America challenges the Marian principle which she refers to as 'marianismo': 'I will spend more time on marianismo because our continent is a Marian continent, and the symbolic significance of Mary is complex and ambiguous', because for 'many women, Mary has modeled their womanhood; for others, she has been the explosive source of deep rebellion and internal rapture' (Del Rio Mena 2015:28). Similarly, Arabome critiques the Church's reduction of women's role to motherhood as oppressive: 'However, the church's rush to endorse woman's role as procreator and helpmate often bypass the positive valorization of the personhood of the African woman in herself' (Arabome 2015:25).

The issue of agency of the oppressed described by Steyn is also reflected by authors in their critique of the Church, for example Militello describes women as follows: 'Women have moved from silence into speech, from invisibility to presence, from submission to coresponsibility' (Militello 2015:10). Similarly Johnson (2015) identifies patriarchy as a practice in the Church that has a historical basis and as the source of women's inequality:

The Church reflects this inequality in all of its aspects. Sacred texts, religious symbols, doctrines, moral teachings, canon laws, 
rituals and governing offices are all designed and led by men. Even God is imagined most often as a powerful patriarch in heaven ruling the earth and its people. In turn, this sacred patriarchy justifies the rule of men over women in family and wider society. (p. 21)

In this regard Johnson is in continuity with Steyn's principle of acknowledging the historical context of oppression as a critical factor in dealing with its contemporary expression. The above citations of authors are a sample of the chapters in the book which has 42 brief chapters of between three and five pages each. The book by CWSN was launched in Rome on 1st October, 2015 before the opening of the Synod of Bishops on the Family and copies were made available to the bishops during the Synod. This concrete intervention at the Synod represents the praxis of the Network which is also reflected in the last principle of Steyn's theory namely oppressed groups taking actions for justice and transformation.

These are some of the significant continuities between Steyn's CDL theory and CWSN. Both make the point that the pursuit for diversity must be rooted in justice and equality. The differences between the two are 'technical'. Steyn developed her theory as an individual academic within the discipline of social theory and by implication in dialogue with other scholars in her field. Further the oppressed and privileged groups who are the target of her theory are involved indirectly as subjects of her research. In contrast the Network is a diverse community of women who as a group experience exclusion, marginalisation and oppression within the Church even though they have different social and geographical locations. Despite these differences the similarities signal that the struggle for justice by oppressed groups operates within a similar framework.

\section{Conclusion}

The construction of difference as inequality underlies the phenomenon of unequal equality reflected in the experiences of both Catholic women and many black students at universities in South Africa. Diversity as a tool of resistance is central to CWSN and Steyn's CDL. The different and yet similar ways in which they appropriate diversity in their struggle for justice attests to the multiple uses of this tool. Both the church and post-apartheid South Africa share a similar vision of an inclusive and diverse community yet CWSN and Steyn's CDL point out these ideals cannot be realised without justice and equality that translates into the full inclusion and participation of groups experiencing the 'unequal equality' phenomenon.

\section{Acknowledgements Competing interests}

The author declares that she has no financial or personal relationships which may have inappropriately influenced her in writing this article.

\section{References}

Arabome, A., 2015, 'Who is Christ for African women?', in Catholic Women Speak Network (eds.), Catholic women speak. Bringing our gifts to the table, pp. 23-26, Paulist Press, New York.

Beattie, T., 2016, 'A place at the table. The story of "Catholic Women Speak'"', Commonweal, viewed 25 April 2016, from https://www.commonwealmagazine.org

Cannon, A., 2015, 'Marriage and divorce: Telling our stories', in Catholic Women Speak Network (eds.), Catholic women speak. Bringing our gifts to the table, pp. 83-85, Paulist Press, New York.

Catechism of the Catholic Church, 2003, The Catechism of the Catholic church, viewed 11 April 2016, from http://www.vatican.va/archive/ENG0015/_INDEX. HTM

Catholic Women Speak Network, (eds.), 2015, Catholic women speak. Bringing our gifts to the table, Paulist Press, New York.

Claque, J., 2015, 'Catholics, families, and the synod of bishops: Views from the Pews', in Catholic Women Speak Network (eds.), Catholic women speak. Bringing our gifts to the table, pp. 51-56, Paulist Press, New York.

Clifford, A.M., 2001, Introducing feminist theology, Orbis, Maryknoll, NY.

Congregation for the Doctrine of the Faith, 1994, Letter to the bishops of the Catholic church concerning the reception of holy communion by the divorced and remarried members of the faithful, viewed 12 April 2016, from http://www.vatican.va/ roman_curia/congregations/cfaith/documents/rc_con_cfaith_doc_14091994_ rec-holy-comm-by-divorced_en.html

Congregation for the Doctrine of the Faith, 2003, Consideration regarding proposals to give legal recognition to Unions between homosexual persons, viewed 12 April 2016, from http://www.vatican.va/roman_curia/congregations/cfaith/documents/ rc_con_cfaith_doc_20030731_homosexual-unions_en.html

Dowsett, G.W., 2003, 'Some considerations on sexuality and gender in the context of AIDS', Reproductive Health Matters 11(22), 21-29.

Del Rio Mena, C., 2015, 'Latin American women: In Mary's footsteps or in her shadow', in Catholic Women Speak Network (eds.), Catholic women speak. Bringing our gifts to the table, pp. 27-31, Paulist Press, New York.

Editorial Team, 2015, 'Introduction', in Catholic Women Speak Network (eds.), Catholic women speak. Bringing our gifts to the table, pp. xxvii-xxxii, Paulist Press, New York.

Espinoza, R. \& Horner, T., 2015, 'Conscience and contraception: Telling our storiesnatural family planning; sharing the struggles', in Catholic Women Speak Network (eds.), Catholic women speak. Bringing our gifts to the table, pp. 92-95, Paulist Press, New York.

Halligan, U., 2015, 'Same-sex love: Telling our stories-"The glory of God is a human being fully alive"', in Catholic Women Speak Network (eds.), Catholic women speak. Bringing our gifts to the table, pp. 113-115, Paulist Press, New York.

International Theological Commission, 2014, Sensus Fidei in the life of the church, viewed 11 April 2016, from http://www.vatican.va/roman_curia/congregations/ cfaith/cti_documents/rc_cti_20140610_sensus-fidei_en.html

John Paul II., 1988, Apostolic Letter Mulieris Dignitatem of the Supreme Pontiff John Paul II on the dignity and vocation of women on the occasion of the Marian Year, viewed 4 April 2016, from https://w2.vatican.va/content/johnpaul-ii/en/apost_letters/1988/documents/hf_jp-ii_apl_19880815_mulierisdignitatem.html

John Paul II, 1995, Letter of Pope John Paul II to women, viewed 4 April 2016, from https://w2.vatican.va/content/john-paul-ii/en/letters/1995/documents/hf_.jp-ii_ let_29061995_women.html

Johnson, E.A., 1993, 'Redeeming the name of Christ,' in LaCugna, C.M. (ed.), Freeing Theology. The Essentials of Theology in Feminist Perspective, pp. 115-137, HarperCollins, New York.

Johnson, E.A., 2015, 'Jesus and women: "You are set free"', in Catholic Women Speak Network (eds.), Catholic women speak. Bringing our gifts to the table, pp. 19-22, Paulist Press, New York.

Kiguwa, P., 2004, 'Feminist critical psychology in South Africa', in Ratele et al. (eds.) Self, community \& psychology, pp. 7-1-7-38, UCT Press, Cape Town.

McElwee, J.J., 2015, 'Francis strongly criticizes gender theory, comparing it to nuclear arms', National Catholic Reporter, viewed 4 April 2016, from http://ncronline.org/ news/vatican/francis-strongly-criticizes-gender-theory-comparing-nuclear-arms

Militello, C., 2015, 'Women in the church: Models of the past-challenges of today', in Catholic Women Speak Network (eds.), Catholic women speak. Bringing our gifts to the table, pp. 7-10, Paulist Press, New York.

Minas, A., 2000, 'Introduction', in A. Minas (ed.), Gender basics feminist perspectives on women and men, pp. 1-8, Stanford, Wadsworth.

Orobator, A.S.J., 2015, 'Foreword: Of listening ears and prophetic voices', in Catholic Women Speak Network (eds.), Catholic women speak. Bringing our gifts to the table, pp. xi-xv, Paulist Press, New York.

Paul VI, 1968, Encyclical Letter Humanae Vitae of the Supreme Pontiff Paul VI, viewed 4 April 2016, from http://w2.vatican.va/content/paul-vi/en/encyclicals/ documents/hf_p-vi_enc_25071968_humanae-vitae.html

Pope Francis, 2006, Post-Synodical Apostolic Exhortation Amoris Laetitia of the Holy Father Francis to bishops, priests and deacons consecrated persons Christian married couples and all the lay faithful, on love in the family, viewed 10 April 2016, from https:// w2.vatican.va/content/dam/francesco/pdf/apost_exhortations/documents/papafrancesco_esortazione-ap_20160319_amoris-laetitia_en.pdf 
Ruether, R.R., 2002, 'The emergence of Christian feminist theology', in S. Parsons \& S. Frank (eds.), The Cambridge companion to feminist theology, pp. 3-22, Cambridge University Press, Cambridge.

Schüssler, F.E., 1998, Sharing her word: Feminist biblical interpretation in context, T \& T Clark, Edinburgh.

Steyn, M., 2015, 'Critical diversity literacy', in S. Vertovec (ed.), Routledge international handbook of diversity studies, pp. 379-389, Routledge, London.
Synod of Bishops, 2014, III Extraordinary General Assembly. The pastoral challenges of the family in the context of evangelization, Instrumentum Laboris. Vatican City, viewed 11 April 2016, from http://www.vatican.va/ roman_curia/synod/documents/rc_synod_doc_20140626_instrumentumlaboris-familia_en.html

Young, I.M., 1990, Justice and the politics of difference, Princeton University Press, Princeton, NJ. 